\title{
Gramsci, filosofia e educação
}

\section{Gramsci, philosophy and education}

\section{Gramsci, filosofía y educación}

\author{
Marcos Francisco Martins*
}

\begin{abstract}
Resumo: Este artigo apresenta uma interpretação da concepção de Gramsci sobre filosofia e educação, bem como da articulação desses conceitos na práxis e no paradigma teórico-metodológico por ele formulado. São utilizados principalmente os textos da maturidade teórico-metodológica de Gramsci, os Cadernos do Cárcere, bem como alguns de seus comentadores que têm forte repercussão no Brasil. O texto é dividido em duas partes: na primeira, é discutida a concepção gramsciana de filosofia e na segunda, a de educação. $\mathrm{Na}$ conclusão, são resgatadas as teses centrais que devem ser levadas em consideração para o que se acredita ser uma boa interpretação do legado filosófico e pedagógico-educativo, resultante do pensamento e da ação de Gramsci, o qual enfrentou as contradições da realidade italiana de sua época na tentativa de colaborar com a superação das relações sociais capitalistas.
\end{abstract}

Palavras-chave: Educação. Filosofia. Gramsci.

\begin{abstract}
This paper presents an interpretation of Gramsci's conception of philosophy and education, as well as the articulation of such concepts in practice and in his theoretical-methodological paradigm. Texts produced mainly in Gramsci's theoreticalmethodological maturity were used such as the Prison notebooks, as well as the writings of some of his reviewers who have strong impact in Brazil. The text is divided into two parts: the first discusses the Gramscian conception of philosophy while the second focuses on his conception of education. In the conclusion, the focus is on central issues which must be taken into account in order to develop a good interpretation of the philosophical and pedagogical-educational legacy originated in Gramsci's thoughts and actions, once he faced the contradictions of the Italian reality of his time in an attempt to cooperate with the overcoming of capitalist social relations.
\end{abstract}

Keywords: Education. Philosophy. Gramsci.

Resumen: Este artículo presenta una interpretación de la concepción de Gramsci sobre filosofía y educación, así como de la articulación de esos conceptos en la praxis y en el paradigma teórico-metodológico por él formulado. Se utilizan principalmente

\footnotetext{
* Professor da Universidade Federal de São Carlos - UFSCar - campus Sorocaba/SP - Bolsista de Produtividade em Pesquisa - CNPq. E-mail: <marcosfranciscomartins@gmail.com>
} 
textos de la madurez teórico-metodológica de Gramsci, los Cuadernos de la Cárcel, así como algunos de sus comentadores con más influencia en Brasil. El texto se divide en dos partes: en la primera se discute la concepción gramsciana de filosofía, mientras en la segunda, la de educación. A modo de conclusión, se rescatan las tesis centrales las cuales deben ser llevadas en consideración para lo que se cree como buena interpretación del legado filosófico y pedagógico-educativo, resultante del pensamiento y de la acción de Gramsci, quien se enfrentó a las paradojas de la realidad italiana de su época en el intento de colaborar con la superación de las relaciones sociales capitalistas.

Palabras clave: Educación. Filosofía. Gramsci.

Criar uma nova cultura não significa apenas fazer individualmente descobertas 'originais'; significa também, e sobretudo, difundir criticamente verdades já descobertas, 'socializá-las' por assim dizer; e, portanto, transformá-las em base de ações vitais, em elemento de coordenação e de ordem intelectual e moral. O fato de que uma multidão de homens seja conduzida a pensar coerentemente e de maneira unitária a realidade presente é um fato 'filosófico' bem mais importante e 'original' do que a descoberta, por parte de um 'gênio filosófico’, de uma nova verdade que permaneça como patrimônio de pequenos grupos intelectuais. (GRAMSCI, 1999, p. 95-96).

\section{Sobre a filosofia de Gramsci}

Gramsci dialogou com as principais correntes filosóficas presentes na cultura italiana e europeia de sua época. Em sua maturidade, contribui, particularmente, para atualizar o materialismo histórico e dialético e para reafirmar a importância revolucionária desse paradigma teórico-metodológico, tendo identificado-o como filosofia da práxis.

Em sua vida e em seu legado teórico, Gramsci entendeu a filosofia como “concepção de mundo" (GRAMSCI, 1999, p. 96). Compreendeu a filosofia como uma maneira de indivíduos e grupos sociais conceberem a realidade e nela orientarem a ação. Disso resultou a tão propalada, e às vezes mal interpretada, assertiva gramsciana de que "[...] todos os homens são 'filósofos"” (GRAMSCI, 1999, p. 93), pois qualquer ser humano tem uma concepção de mundo, seja resultante da própria autonomia do sujeito, seja incutida nele por meios diversos.

Muito embora Gramsci entenda por filosofia as concepções de mundo, essas não são concebidas por ele apenas e tão somente como produtos da subjetividade ou da intersubjetividade. Pelo contrário, entende-as como forjadas no calor das relações sociais que se desenvolvem em uma concreta formação econômica e social, e têm papel importante na consolidação ou na superação do modo de produção e reprodução da vida social vigente. 
Destarte, as filosofias são, ao mesmo tempo, produtos e produtoras das relações sociais, e emergem no devir histórico de uma formação econômica e social. Eis uma característica marcante do marxismo gramsciano: as formações econômicas e sociais não são determinadas exclusivamente pelos movimentos da estrutura, mas na dialética relação da base material com a superestrutura social. Foi por essa concepção que o conceito de filosofia amadureceu ${ }^{1} \mathrm{em}$ Gramsci, tendo, porém, suscitado alguns equívocos.

Bobbio, p. e., interpretou enviesadamente o dialético legado de Gramsci, pois o entendeu como um autor que teria "[...] colocado 'o verdadeiro centro, o teatro da história' [...]" (BOBBIO, 1982, p. 33) na "[...] sociedade civil, [que] em Gramsci, não pertence ao momento da estrutura, mas ao da superestrutura." (BOBBIO, 1982, p. 32, grifo do autor). Essa interpretação bobbiana da relação entre estrutura e superestrutura em Gramsci supõe que na determinação da totalidade sóciohistórica a base material perderia completamente seu peso (cf. MARTINS, 2008a, 2008b), sendo o âmbito superestrutural o primeiro e o último determinante da realidade concreta, o que seria suficiente para torná-lo um idealista identificado com Hegel e Croce, e não com Marx, Engels e Lênin, como apontam os textos de sua maturidade teórica e sua práxis.

Diferentemente da interpretação de Bobbio, pode-se observar na obra teórica e na prática social de Gramsci que ele interpretou as determinações sóciohistóricas à luz do estágio de desenvolvimento do capitalismo de seu tempo, que era consideravelmente diferente daquele vivido no europeu século precedente. $\mathrm{Na}$ realidade europeia vivida por Marx e Engels, o século XIX, e a de Lênin, a Rússia das duas primeiras décadas do século XX, o poder encontrava-se concentrado no estado, que se constituía como um mecanismo predominantemente coercitivo (LÊNIN, 1986, p. 15-22) por meio do qual a classe dominante economicamente - burguesia - garantia a reprodução do modo de vida pela força dos aparelhos da "sociedade política" (cf. GRAMSCI, 2001, p. 262). Contudo, na primeira metade do século XX, nos países capitalistas mais desenvolvidos, essa dinâmica de funcionamento das relações sociais alterou-se na medida do desenvolvimento das forças produtivas e das mudanças no modo de produção e reprodução da vida social, as quais incidiram sobre a estrutura e a superestrutura. Essas alterações modificaram a conformação do estado, em particular, e das relações sociais, em geral, exigindo novas estratégias aos que pretendiam promover a superação do capitalismo, como o próprio Engels mencionou, na Introducão de As lutas de classes em França:

\footnotetext{
1"A formação inicial de Gramsci foi liberal. A filosofia dos dois maiores expoentes do neo-idealismo e do liberalismo, Benedetto Croce e Giovanni Gentile, constitui o seu referencial teórico para analisar a Itália moderna e não as ideias positivistas e naturalistas de Guglielmo Ferrero e Filippo Turati, representantes do Partido Socialista Italiano." (LOSURDO, 2006, p. 292).
} 
[...] se as condições da guerra entre as nações se modificaram, também para a luta de classes não se modificaram menos. O tempo dos ataques de surpresa, das revoluções levadas a cabo por pequenas minorias conscientes à frente das massas inconscientes, já passou. Sempre quando se trata de uma transformação completa da organização social são as próprias massas que devem estar metidas nelas [...] Isto foi o que a história dos últimos cinquenta anos nos ensinou. (MARX, 1984, p. 26-27).

Seguindo a indicação de Engels ${ }^{2}$, Gramsci perscrutou a realidade e sua práxis o levou a atualizar a forma de luta do proletariado, de acordo com as novas condições sócio-históricas das sociedades capitalistas avançadas. Desenvolvendo o "[...] que Ilitch [Lênin] não teve tempo de aprofundar" (GRAMSCI, 2000b, p. 262), Gramsci observou que o estado havia alterado sua configuração, ampliando-se e abarcando, além dos aparelhos de força da "sociedade política", os "aparelhos privados de hegemonia" (sociedade civil), que são necessários para manter a prevalência dos interesses burguesia na dinâmica de funcionamento das relações sociais (GRAMSCI, 2005, p. 84). Assim, o estado, no século XX, segundo Gramsci, não deixou de ser um instrumento de classe a serviço da burguesia, mas mudou sua estratégia de ação e sua configuração (GRAMSCI, 2000b, p. 262): foi além da utilização da força e da coerção, agindo para cimentar concepções de mundo que pudessem orientar a vida individual e coletiva dos integrantes da totalidade social, de acordo com os interesses e as necessidades da burguesia como classe dominante, com vistas a mantê-la como classe hegemônica ${ }^{3}$. Incorporados ao Estado, os instrumentos e processos da sociedade política, pela força, e os da sociedade civil, pela promoção do consenso, articulam, segundo Gramsci, uma "trama privada" com vistas à consolidação da hegemonia das classes dominantes e dirigentes, isto é, educa as massas (MANACORDA, 1990, p. 125-126). Disso resultou uma realidade em que a classe dominante ampliou sua hegemonia para além do âmbito econômico e político, alastrando-se para outras dimensões: ética, cultural, estética, psicológica, social, religiosa etc. (cf. Americanismo e fordismo - GRAMSCI, 2001, p. 237-282). Ou seja,

\footnotetext{
${ }^{2}$ Engels mencionou, em As lutas de classes em França, que "Porém, a história também não nos deu razão e demonstrou que os nossos pontos de vista dessa altura eram uma ilusão. E foi ainda mais além: não só destruiu o nosso erro de então como revolucionou totalmente as condições em que o proletariado tem de lutar. O modo de luta de 1848 está hoje ultrapassado em todos os aspectos. E este é um ponto que merece ser examinado mais de perto [...]" (MARX, 1984, p. 16, grifo nosso).

3 “Lênin e o leninismo são, portanto, por detrás da cifrada linguagem 'carcerária', os pontos de referência de Gramsci na elaboração do conceito de hegemonia.” (MANACORDA, 1990, p. 104) Mais do que isso, se pode dizer que "Antonio Gramsci, sem nenhuma dúvida, foi o teórico marxista que mais insistiu sobre o conceito de hegemonia; e o fez reclamando-se particularmente de Lênin. Aliás, diria mesmo que, se se quer ver o ponto de contato mais constante, mais enraizado, de Gramsci com Lênin, esse me parece ser o conceito de hegemonia. A hegemonia é o ponto de confluência de Gramsci com Lênin.” (GRUPPI, 1978, p. 1).
} 
A novidade da concepção gramsciana de hegemonia é distinguir os dois modos pelos quais ela se manifesta: um pelo domínio, outro, pela direção moral e intelectual. Um grupo social básico domina quando liquida ou submete o grupo adversário; dirige quando se põe à frente dos grupos afins ou aliados. $\mathrm{O}$ domínio supõe o acesso ao poder e o uso da força, compreendendo a função coercitiva; a direção intelectual e moral se faz através da persuasão, promove a adesão por meios ideológicos, constituindo a função propriamente hegemônica. (CARDOSO, 1978, p. 73, grifo do autor).

Se a passagem ao socialismo no século XIX, bem como na primeira e na segunda década do século XX, tentou-se fazer pelas recomendações e tradições do marxismo originário (MARX; ENGELS, 1997, p. 44 e 67), isto é, por meio de uma "guerra de movimento", pela revolução entendida como assalto ao poder, a nova realidade exigiu que a revolução se desenvolvesse utilizando-se também ${ }^{4}$ da estratégia da "guerra de posição" (GRAMSCI, 2000b, p. 24), da luta em todos os espaços e ambientes sociais para contradizer a concepção de mundo burguesa - seus conceitos, valores, verdades, hábitos sociais etc. - e para disseminar outra filosofia afeita às classes subalternas, com o objetivo de angariar força suficiente para forjar um bloco social capaz de impor novas dinâmicas sociais e, assim, produzir uma verdadeira reforma moral e intelectual ${ }^{5}$.

Em outros termos, pode-se colocar essa questão da seguinte forma: para Gramsci, muitas filosofias emergiram das necessidades do processo de consolidação da burguesia como classe dominante economicamente e dirigente sob o ponto de vista ético-político e cultural, o que tornava cada vez mais um imperativo forjar filosofias coerentes com as necessidades de as classes subalternas libertarem-se da submissão ético-política, exploração econômica e da alienação social que as caracteriza como classe social subalterna. De fato,

Começa a ficar claro, para Gramsci, que a luta de classe não se resolve na fábrica, nem na conquista do poder político através do enfrentamento 'físico' com a burguesia. Existe, difusa na sociedade, uma concepção do mundo e da vida, que dá força e sustentação às relações sociais que intercorrem entre operários e burguesia, entre operários e camponeses, entre latifundiários e trabalhadores assalariados do campo, entre norte e sul do país [...] Amplia-se, assim, enormemente o campo de análise, forçando Gramsci a ver a esfera do político dentro de um contexto maior, dentro de uma totalidade que abrange,

\footnotetext{
${ }^{4}$ Gramsci não rejeita a "guerra de movimento" em favor da "guerra de posição", pois assim se tornaria um idealista, um socialista utópico na luta social, o que não coaduna com seu legado teórico e militância política.

5 "Pode haver reforma cultural, ou seja, elevação civil das camadas mais baixas da sociedade, sem uma anterior reforma econômica e uma modificação na posição social e no mundo econômico? É por isso que uma reforma intelectual e moral não pode deixar de estar ligada a um programa de reforma econômica; mais precisamente, o programa de reforma econômica é exatamente o modo concreto através do qual se apresenta toda reforma intelectual e moral." (GRAMSCI, 2000b, p. 19).
} 
além das forças produtivas e de suas organizações, também as forças ideológicas e culturais, que desenvolvem um papel oculto importante na formação e conservação dos sistemas sociais. (STACCONE, 1995, p. 70, grifo do autor).

Percebe-se que esse entendimento gramsciano sobre a dinâmica de funcionamento das formações econômicas e sociais não é originário exclusivamente de suas reflexões teóricas, de suas meditações de gabinete, ou melhor, de seus pensamentos nas celas das prisões fascistas que frequentou, mas também, e principalmente, de sua práxis. Destaque-se, com relação à sua práxis, o aprendizado resultante do fracassado processo para tentar implantar a revolução na Itália durante o "biênio vermelho" (1919 e 1920), após o qual Gramsci superou as anteriores concepções teóricas e a prática política: o limitado sardismo da fase da juventude, o socialismo voluntarista que o caracterizava na chegada a Turim e mesmo a convicção do inexorável sucesso da "guerra de movimento" empreendida pelos "Conselhos de fábrica".

$\mathrm{Na}$ verdade, a derrota da revolução na Itália teve profundas implicações teóricas e consequências ético-políticas importantíssimas ao amadurecimento de Gramsci e ao desenvolvimento do movimento socialista e comunista italiano. Nesse transcurso, Gramsci concebeu sua noção de filosofia na dialética visão que tem da relação entre estrutura e superestrutura, segundo a qual a configuração das relações sociais acompanha os resultados da correlação de forças que se estabelece entre as classes sociais fundamentais no modo de produção capitalista. Amadurecido com essa dialética concepção, Gramsci, com suas formulações, mormente as desenvolvidas no cárcere, corroborou a tese marxiana da relação entre ser e pensar: "Para a filosofia da práxis o ser não pode ser separado do pensar, o homem da natureza, a atividade da matéria, o sujeito do objeto; se se faz esta separação, cai-se numa das muitas formas de religião ou na abstração sem sentido." (GRAMSCI, 1999, p. 175).

Essa noção da interação entre ser e pensar, com implicações ontológicas, antropológicas ${ }^{6}$, epistemológicas e axiológicas, possibilitou a Gramsci entender que as concepções de mundo se apresentam como determinadas e determinantes da vida concreta, e que nesse jogo de interatuação entre objetivo e subjetivo na realidade sócio-histórica emergem diferentes filosofias, desde as mais elaboradas, coerentes e sintéticas, até as que se caracterizam por serem visões superficiais e sincréticas de mundo, mas todas elas com uma mesma origem, pois são produto de "[...] um devir histórico [que faz com que] $\mathrm{Na}$ realidade, [...] exist[am] diversas [...] concepções de mundo.” (GRAMSCI, 1999, p. 96).

\footnotetext{
6 "O seu [de Gramsci] conceito de homem é um conceito relacional ('o homem é o conjunto das relações sociais'), mas, na realidade, é alguma coisa a mais: é um conceito estruturado. No entanto, as relações que o indivíduo estabelece e aquelas nas quais está inserido têm um componente sincrônico e um diacrônico; têm uma relação com a estrutura social e uma dimensão histórica. O homem pode, portanto, ser definido, como um 'bloco histórico'. As relações sociais estão entrosadas nas formas e nas estruturas sociais (vizinhança, família, relações de trabalho, grupos sociais fundamentais, extratos sociais etc.)" (RAGAZZINI, 2005, p. 146).
} 
Gramsci identifica pelo conceito de senso comum as concepções de mundo que expressam visões superficiais, ingênuas, a-críticas e incoerentes da realidade, e que misturam noções de ciências, de experiências individuais, princípios religiosos etc. $\mathrm{O}$ senso comum é a

[...] concepção de mundo absorvida acriticamente pelos vários ambientes sociais e culturais nos quais se desenvolve a individualidade moral do homem médio. O senso comum não é uma concepção única, idêntica no tempo e no espaço: é o "folclore" da filosofia [...] seu traço mais fundamental e mais característico é o de ser uma concepção (inclusive nos cérebros individuais) desagregada, incoerente, inconsequente, conforme a posição social e cultural das multidões das quais ele é a filosofia [...] Os elementos principais do senso comum são fornecidos pelas religiões e, consequentemente, a relação entre senso comum e religião é muito mais íntima do que a relação entre senso comum e sistemas filosóficos dos intelectuais [...] Predominam no senso comum os elementos "realistas", materialistas, isto é, o produto imediato da sensação bruta, o que, de resto, não está em contradição com o elemento religioso, ao contrário; mas estes elementos são "supersticiosos", acríticos [...]. (GRAMSCI, 1999, p. 114-115).

Para Gramsci, o senso comum é a "[...] filosofia dos não filósofos" (GRAMSCI, 1999, p. 114), amplamente difundida e aceita pelo coletivo social. Contudo, Gramsci não se deixou levar pela neutralidade dos conceitos, pois para ele, o senso comum, no âmbito do modo de vida capitalista, expressa uma concepção de mundo adequada à classe dominante e dirigente, pois é resultante da dinâmica social, ao mesmo tempo em que a retroalimenta, visando a consolidála. Isso porque o senso comum é difundido por diferentes meios - mídia, escola, literatura, teatro, religião, relações familiares etc. -, ao ponto de ser absorvido, apreendido acriticamente pelos indivíduos e pelos grupos sociais para que possa lhes servir como orientação frente aos dilemas da vida individual e aos problemas que a formação econômica e social enfrenta coletivamente, estabelecendo limites ao padrão de comportamento e ao desenvolvimento moral; p. e.: ao difundir a indiferença e a passividade política e mesmo ao justificar a ordem econômica, social, política e cultural vigente.

Assim entendido, o senso comum, para Gramsci, não se reduz a uma ideia amplamente aceita ou a uma formulação ingênua sobre o homem e suas relações, pois é uma concepção de mundo com interesses e compromissos que visam ao consentimento social em relação à dominação e direção de uma classe sobre as demais, por meio da implantação de um conformismo ativo, de forma a torná-las subalternas. É, portanto, um dos elementos que interatuam na realidade concreta, participando do processo de determinação dos rumos históricos da formação econômica e social, conforme reconheceram Marx e Engels com a 
"[...] proposição da filosofia da práxis que [diz] [...] que as 'crenças populares' ou as crenças do tipo das crenças populares têm a validade das forças materiais." (GRAMSCI, 2000b, p. 53).

Embora Gramsci tenha entendido a filosofia como concepção de mundo - e, nesse sentido, o senso comum também é uma filosofia, a "filosofia dos não filósofos" -, ele a reconhece como "[...] uma ordem intelectual, o que nem a religião e nem o senso comum podem ser. A filosofia é a crítica e a superação da religião e do senso comum.” (GRAMSCI, 1999, p. 96). Há entre filosofia e senso comum similaridades e distinções.

Entre as similaridades está o fato de que tanto a filosofia quanto o senso comum são concepções de mundo elaboradas na trama de contradições do devir histórico das relações sociais e são difundidos por diferentes meios, com vistas ou a conservar a configuração societária vigente ou a superá-la. Mas há também distanciamentos significativos entre eles. Diferentemente do senso comum, a filosofia, para Gramsci, é uma ordem intelectual (GRAMSCI, 1999), o que a afasta do acriticismo e da incoerência que caracterizam o senso comum.

A pretensão da filosofia é se tornar um novo senso comum, mas renovado e sujeito a novas reflexões e críticas para ser superado novamente. Nas palavras de Gramsci (1999, p. 100-101),

Talvez seja útil distinguir "praticamente" entre a filosofia e o senso comum, para melhor indicar a passagem de um momento para o outro. Na filosofia, destacam-se notadamente as características de elaboração individual do pensamento; no senso comum, ao contrário, destacam-se as características difusas e dispersas de um pensamento genérico de uma certa época em certo ambiente popular. Mas toda filosofia tende a se tornar senso comum de um ambiente, ainda que restrito [...] Trata-se, portanto, de elaborar uma filosofia que - tendo já uma difusão ou possibilidade de difusão, pois ligada à vida prática e implícita nela - se torne um senso comum renovado com a coerência e o vigor das filosofias individuais. E isto não pode ocorrer se não se sente, permanentemente, a exigência do contato cultural com os "simples".

A filosofia também é, como o senso comum, uma concepção de mundo com interesses e compromissos com as classes fundamentais. São as contradições sociais que mobilizam as forças necessárias ao surgimento das filosofias, e no capitalismo das modernas sociedades ocidentais, não há filosofia sem a marca da luta entre as classes fundamentais. "É por isso, portanto, que não se pode destacar a filosofia da política; ao contrário, pode-se demonstrar que a escolha e a crítica de uma concepção de mundo são, também elas, fatos políticos." (GRAMSCI, 1999, p. 97). Nesse sentido, para Gramsci, a luta de classes está na origem das filosofias, e essas retroalimentam a mesma luta que a precedeu 
logicamente (as filosofias são concepções de mundo de homens e mulheres que vivem concretamente os dramas das contradições sociais e em suas vidas vão desenvolvendo suas concepções de mundo), por meio de um processo dialético, que é incapaz de ser explicado pela teoria da causalidade, porque esse paradigma não alcança a relação recíproca entre os elementos que interatuam na realidade para produzi-la e reproduzi-la (cf. Cadernos filosóficos - LÊNIN, 1972).

Em se tratando, particularmente, das filosofias que se pretendem orgânicas às classes subalternas, elas devem identificar e desenvolver o "[...] núcleo sadio do senso comum, que poderia ser chamado de bom senso e que merece ser desenvolvido e transformado em algo unitário e coerente" (GRAMSCI, 1999, p. 98), impactando epistemológica e ético-politicamente a realidade sócio-histórica. E isso porque, ao partir do senso comum, de seu "núcleo sadio", o bom senso, é possível elaborar uma nova concepção de mundo, que precisará ser difundida em todos os espaços e ambientes sociais, mas priorizando como alvo os indivíduos e grupos sociais das classes subalternas para que, identificadas com a nova filosofia, a ela se articulem para superar seus comportamentos individuais e coletivos, fazendo-os caminhar na direção da transformação radical das estruturas e superestruturas sociais, promovendo "[...] um grande progresso filosófico, já que implica e supõe necessariamente uma unidade intelectual e uma ética adequada a uma concepção do real que superou o senso comum e tornou-se crítica [...]" (GRAMSCI, 1999, p. 104).

Papel importante nesse processo de elaboração de concepções de mundo, eivado pela luta de classes, desempenham os intelectuais ${ }^{7}$, que para Gramsci não se restringem a indivíduos, especialmente os diplomados, como recorrentemente eles são identificados, mas podem ser também organismos sociais coletivos. Intelectuais são todos os que se mobilizam para conceber e/ou disseminar uma concepção de mundo articulada aos compromissos com as classes sociais vigentes (tarefa dos intelectuais orgânicos a elas, isto é, daqueles que manifestam compromisso vital com a consolidação como classe social hegemônica) ou mesmo com os grupos sociais que são remanescentes de formações econômicas e sociais pretéritas, mas que ainda continuam articulados (intelectuais tradicionais, como, p. ex., eram os clérigos católicos à época de Gramsci na Itália do princípio do século $\left.X X^{8}\right)$.

\footnotetext{
7 Todo grupo social, nascendo no terreno originário de uma função essencial no mundo da produção econômica, cria para si, ao mesmo tempo, organicamente, uma ou mais camadas de intelectuais que lhe dão homogeneidade e consciência da própria função, não apenas no campo econômico, mas também no social e no político (GRAMSCI, 2000a, p. 15).

8 “'Todo grupo social 'essencial', contudo, emergindo na história a partir da estrutura econômica anterior e como expressão do desenvolvimento dessa estrutura, encontrou - pelo menos na história que se desenrolou até aos nossos dias - categorias de intelectuais preexistentes, as quais apareciam, aliás, como representantes de uma continuidade histórica que não foi interrompida nem mesmo pelas mais complicadas e radicais modifi-
} 
São três, basicamente, as tarefas dos intelectuais orgânicos à classe dominante e dirigente ou às classes subalternas: a científico-filosófica, a educativo-cultural e a ético-política (MARTINS, 2011a). A primeira tarefa dos intelectuais orgânicos é a de compreender a dinâmica socioeconômica, política e cultural das sociedades em que vivem, para estarem preparados para formular uma concepção de mundo que seja condizente com os interesses e necessidades da classe a que está organicamente vinculado. A tarefa educativa-cultural identifica o trabalho que os intelectuais orgânicos desenvolvem para disseminar e cimentar as concepções de mundo, tornando-as referência na delimitação de comportamentos individuais e coletivos. A tarefa ético-política é a que os intelectuais orgânicos desenvolvem na mobilização de indivíduos e grupos sociais com vista a articulá-los em torno da concepção de mundo forjada, que visa a adequar a subjetividades às funções práticas. Em síntese, para Gramsci, a “[...] tarefa dos intelectuais é determinar e organizar a reforma moral e intelectual, isto é, adequar a cultura à função prática [...]" (GRAMSCI, 1999, p. 126). É por isso que, para Gramsci, os intelectuais são os "funcionários da superestrutura" (GRAMSCI, 2000a, p. 20).

Contudo, o trabalho dos intelectuais só será producente se as filosofias que formularam se disseminarem a tal ponto de se tornarem vontade, transformarem-se em uma força social que opera objetivamente na história, isto é, em ideologia.

[...] nesse ponto, coloca-se o problema fundamental de toda concepção de mundo, de toda filosofia que se transformou em um movimento cultural, em uma "religião", em uma "fé", ou seja, que produziu uma atividade prática e uma vontade nas quais ela esteja contida como "premissa" teórica implícita (uma ideologia, pode-se dizer, desde que se dê ao termo "ideologia" o significado mais alto de uma concepção de mundo, que se manifesta implicitamente na arte, no direito, na atividade econômica, em todas as manifestações de vida individuais e coletivas) - isto é, o problema de conservar a unidade ideológica em todo o bloco social que está cimentado e unificado justamente por aquela determinada ideologia. A força das religiões, e notadamente da Igreja Católica, consistiu e consiste no seguinte: elas sentem intensamente a necessidade de união doutrinária de toda a massa "religiosa" e lutam para que os estratos intelectualmente superiores não se destaquem dos inferiores. (GRAMSCI, 1999, p. 98-99).

cações das formas sociais e políticas. A mais típica dessas categorias de intelectuais é a dos eclesiásticos, que monopolizaram durante muito tempo [...] alguns serviços importantes: a ideologia religiosa, isto é, a filosofia e a ciência da época, com a escola, a instrução, a moral, a justiça, a beneficência, a assistência, etc. A categoria dos eclesiásticos pode ser considerada como a categoria intelectual organicamente ligada à aristocracia fundiária [...] Mas o monopólio das superestruturas por parte dos eclesiásticos [...] não foi exercido sem luta e sem limitações; e nasceram [...] outras categorias [...] Dado que estas várias categorias de intelectuais tradicionais sentem com ‘espírito de grupo' sua ininterrupta continuidade histórica e sua ‘qualificação', eles se põem a si mesmos como autônomos e independentes do grupo social dominante.” (GRAMSCI, 2000, p. 16-17, grifo nosso). 
Assim compreendido, o conceito de ideologia em Gramsci não se reduz ao simples conjunto de ideias que indivíduos e organizações sociais manifestam de diferentes formas, e nem muito menos, à "ciência das ideias" ou à "falsa consciência", pois é uma concepção de mundo originária das contradições sociais que ganha materialidade na dinâmica histórica das relações sociais, na medida em que se torna capaz de orientar as ações individuais e coletivas. "Para Gramsci, as ideologias não são "aparência" ou "falsa consciência", mas constituem um terreno contraditório, no qual os conflitos sociais tanto podem ser ocultados quanto esclarecidos." (DORE, 2006, p. 336). Daí que "A maneira pela qual o conceito de ideologia [...] passou a significar [...] deve ser examinado historicamente [...]" (GRAMSCI, 1999, p. 208).

Na verdade, "Encontro a categoria explicativa da produção ideológica nas sociedades de classe na reflexão gramsciana, no seu conceito de hegemonia." (CARDOSO, 1978, p. 72). A ideologia está presente na dialética relação entre as classes fundamentais pelo domínio e pela direção, e nela se apresenta como uma concepção de mundo que se expressa não apenas como ideia, mas como vontade coletiva. E se conseguir se constituir efetivamente como vontade coletiva, terá mais condições de interferir na disputa pela hegemonia entre as classe.

Assim sendo, a ideologia em Gramsci não se resume a uma concepção da classe dominante e dirigente que, por meio dos aparelhos ideológicos do estado, consolida suas necessidades e interesses sobre todos os grupos da totalidade social. Há na concepção de ideologia de Gramsci espaço para ideologias das classes subalternas, influenciado que foi pela tese leninista de que "[...] não podia haver cultura socialista sem revolução e nem [...] a edificação do socialismo 'sem a elevação do nível cultural das massas” (JESUS, 2005, p. 51). A propósito disso, parte da contribuição de Gramsci ao desenvolvimento do conceito de ideologia refere-se à identificação que ele faz de seus tipos.

\footnotetext{
${ }^{9}$ Recorrentemente, são feitas comparação entre a concepção de ideologia de Gramsci e a de Marx, esta tomada como sendo sinônimo de "falsa consciência", uma concepção presente em $A$ ideologia alemã. Mas, a ideologia em Marx não se restringe ao significado de falsa consciência. De um lado, pode-se dizer que, no referido texto, o que Marx está a fazer é dirigindo uma crítica aos irmãos Bauer, sem a preocupação de definir o conceito de ideologia expressa e cabalmente. Não fosse assim, seria difícil compreender outras passagens das obras de Marx e Engels, como a seguinte, que aparece na Crítica à filosofia do direito de Hegel: "A arma da crítica não pode, decerto, substituir a crítica das armas; a força material só será derrubada pela força material; mas a teoria em si torna-se também uma força material quando se apodera das massas.” (MARX, 2008, p. 14). Ou mesmo a que está no Prefácio Para a crítica da economia política: é "[...] pelas formas ideológicas [que] os homens tomam consciência deste conflito e o conduzem até o fim" (MARX, 1991, p. 30). O que tais passagens indicam, bem como uma leitura mais atenta das demais obras dos marxistas originários, é que a concepção de ideologia de Marx e Engels não se reduz à "falsa consciência", pelo contrário, demonstra a importância da ideologia para a luta revolucionária. Gramsci retomou o conceito do marxismo originário e, inspirado por Lênin, o desenvolveu a partir dos novos desafios que o desenvolvimento do capitalismo impôs aos que pretendiam sua superação.
} 
É necessário, por conseguinte, distinguir entre ideologias historicamente orgânicas, isto é, que são necessárias a uma determinada estrutura, e ideologias arbitrárias, racionalísticas, "voluntaristas". Enquanto são historicamente necessárias, as ideologias têm uma validade que é validade psicológica: elas "organizam" as massas humanas, forma o terreno no qual os homens se movimentam, adquirem consciência de sua posição, lutam etc. Enquanto são "arbitrárias", não criam mais do que "movimentos" individuais, polêmicas, etc. [A] Validade das ideologias recorda[r] a frequente afirmação de Marx sobre a "solidez das crenças populares [...] Outra afirmação de Marx é a de que uma persuasão popular tem, com frequência, a mesma energia de uma força material [...] que é muito significativa. (GRAMSCI, 1999, p. 238, grifo nosso).

Como se percebe, as ideologias arbitrárias são interpretadas negativamente por Gramsci. As orgânicas, pelo contrário, são as que se forjam segundo as necessidades de certa estrutura social, podendo ter significado positivo, como é o caso das ideologias do proletariado, por exemplo. Desta feita, na visão gramsciana, as filosofias podem operar objetivamente na história quando se tornam ideologias.

Para que as classes subalternas construam ideologias operantes objetivamente na história, elas devem passar por um processo chamado por Gramsci de catártico. Segundo ele,

Pode-se empregar a expressão "catarse" para indicar a passagem do momento meramente econômico (ou egoísta-passional) ao momento ético-político, isto é, a elaboração superior da estrutura em superestrutura na consciência dos homens. Isto significa, também, a passagem do "objetivo ao subjetivo" e da "necessidade à liberdade". A estrutura, de força exterior que esmaga o homem, assimilando-o e o tornando passivo, transforma-se em meio de liberdade, em instrumento para criar uma nova forma ético-política, em origem de novas iniciativas. A fixação do momento "catártico" torna-se assim, parece-me, o ponto de partida de toda filosofia da praxis, o processo catártico coincide com a cadeia de sínteses que resultam do desenvolvimento dialético. (GRAMSCI, 1999, p. 314-315).

Pelo conceito de catarse (MARTINS, 2011b), mais uma vez Gramsci manifesta a complexidade do pretendido processo de transformação radical das relações sociais capitalistas, que passa por transformações estruturais e, ao mesmo tempo, dialeticamente, por superações ao nível das consciências individuais e coletivas. Desse modo, o desenvolvimento da luta política, que deve envolver as massas subalternas, implica um processo de elevação das consciências, articulando ao aspecto objetivo o subjetivo nessa empreitada que 
[...] correspondem a diversos momentos da consciência política coletiva [...] O primeiro e mais elementar é o econômico-corporativo [...] [quando] sente-se a unidade homogênea do grupo profissional e o dever de organizá-la, mas não ainda a unidade do grupo social mais amplo. Um segundo momento é aquele em que se adquire a consciência da solidariedade de interesses entre todos os membros do grupo social, mas ainda no campo meramente econômico. Já se põe neste momento a questão do Estado, mas apenas no terreno da obtenção de uma igualdade político-jurídica com os grupos dominantes [...] Um terceiro momento é aquele em que se adquire a consciência de que os próprios interesses corporativos [...] superam o círculo corporativo, de grupo meramente econômico, e podem e devem tornar-se os interesses de outros grupos subordinados. Esta é a fase mais estreitamente política, que assinala a passagem nítida da estrutura para a esfera das superestruturas complexas; é a fase em que as ideologias geradas anteriormente se transformam em "partido", entram em confrontação e lutam até que uma delas, ou pelo menos uma única combinação delas, tenda a prevalecer, a se impor, a se irradiar em toda a área social, determinando, além da unicidade dos fins econômicos e políticos, também a unidade intelectual e moral [...] criando, assim, a hegemonia de um grupo social fundamental sobre uma série de grupos subordinados. (GRAMSCI, 2000b, p. 41).

Assim sendo, “[...] a conquista da hegemonia e o nascimento de um grupo social para a história estão ligados a uma dialética que atravessa essencialmente a autorrepresentação que aquele grupo possui de si mesmo [...]" (FINELLI, 2001, p. 02) sem desconsiderar que

[...] é no campo das experiências concretas, na interlocução crítica com a cultura e no embate com os projetos políticos existentes no movimento real da história que, para Gramsci, se chega progressivamente à compreensão de si mesmo, à elaboração de uma própria concepção de mundo, de uma teoria do conhecimento e à construção de métodos [...] Para Gramsci, de fato, como para Marx, o pensamento é parte integrante da realidade e existe uma ligação inseparável entre o agir e o conhecer. (SEMERARO, 2001, p. 96).

Interessa, por fim, observar que essa compreensão dialética da articulação entre estrutura e superestrutura, da qual resulta a concepção politizada de filosofia foi, também, o caldo cultural que levou Gramsci a combater várias filosofias e ideologias de sua época. Entre as concepções de mundo que Gramsci combateu há uma, em especial, entre elas que se apoderou dos militantes com os quais o revolucionário italiano da Sardenha cerrou fileiras: o materialismo vulgar, que inspirou a positivização do marxismo desenvolvida por muitos dirigentes socialistas e comunistas, como Guglielmo Ferraro e Filipo Turati, dirigentes do Partido Socialista Italiano, bem como de Bukharin. Em geral, o que identifica essas concepções de mundo é a assertiva segundo a qual o sujeito nada pode frente à 
determinação da estrutura econômica, pois é entendida como determinante do sujeito em todas as suas dimensões. Eis uma tese rechaçada por Gramsci.

Gramsci sustentou a crítica ao mecanicismo marxista inspirando-se, sobretudo, na juventude, na "[...] filosofia dos dois maiores expoentes do neoidealismo e do liberalismo, Benedeto Croce e Giovanni Gentile" (LOSURDO, 2006, p. 292). Mas essa perspectiva implicava outro problema, qual seja fundar o marxismo em bases especulativas, tendo como decorrência que o sujeito pode tudo, independentemente de sua situação concreta de vida. Daí a crítica de Gramsci dirigida a tais correntes de pensamento.

O caminho filosófico seguido por Gramsci foi o de sustentar sua concepção de mundo na máxima ontológica da dialética do marxismo originário: "O concreto é concreto porque é síntese de múltiplas determinações, isto é, unidade do diverso." (MARX, 1991, p. 16), e como método adotou a referência epistemológica maior desse mesmo paradigma teórico metodológico: análise concreta de situações concretas (cf. MARX, 1991, p. 16-17). Assim, obviamente, as influências croceanas e gentilianas foram superadas posteriormente, tornando a concepção filosófica de Gramsci caracterizada pela radicalidade do conceito de dialética, sem abandonar o "[...] princípio básico do materialismo histórico: o de que a produção e reprodução da vida material, implicando a produção e reprodução das relações sociais globais, é fator ontologicamente primário na explicação da história." (COUTINHO, 1999, p. 123).

\section{Princípios e finalidades da educação em Gramsci}

Ao sustentar-se ontológica, axiológica e epistemologicamente no marxismo, mas em um marxismo que prima pela dialética, Gramsci enfrentou dificuldades para formular sua proposta educativa. Sua concepção de educação, assim como sua filosofia, tem a marca da luta de classes e se forjou sob a égide da dialética relação entre estrutura e superestrutura.

O conceito de educação em Gramsci desenvolveu-se acompanhamento seu amadurecimento teórico do neo-idealismo ao materialismo histórico e dialético. Se até o biênio vermelho o seu conceito de educação era bastante marcado pela noção de cultura desinteressada, posteriormente a esse evento e, principalmente, no cárcere, Gramsci formulou as linhas gerais de sua proposta educativa, fundada no trabalho como princípio educativo e na revolução das relações sociais capitalistas como finalidade. Dessa forma, a reflexão sobre a educação feita por Gramsci traz a marca da intencionalidade de um comunista revolucionário porque se articula como uma estratégia de passagem ao socialismo nas sociedades ocidentais. 
Ocorre que, nas modernas sociedades ocidentais, Gramsci observou que a estrutura constitui poderosos mecanismos de reprodução (políticos e ideológicos) da vida social, sendo a escola um deles, e também a Igreja, os meios de comunicação etc. Esses instrumentos da sociedade civil mediatizam a determinação em última instância das relações sociais de produção e, justamente por isso, acabam configurando-se com duplo papel no complexo superestrutural: podem ser utilizados para consolidar a hegemonia em vigor, espelhando as concepções de mundo das classes dominantes e dirigentes até torná-las uma ideologia eficiente na reprodução das relações sociais, cimentando as condições para o fortalecimento do bloco histórico vigente, ou ser utilizados para combatê-lo, difundindo por todos os meios sociais uma nova visão de mundo forjada pelas classes subalternas e seus intelectuais orgânicos, com vistas a construir uma nova civilização. "Nesse sentido, o problema da revolução é também um problema de educação.” (GRISONI; MAGGIORI, 1973, p. 33).

Muito embora seja a educação um processo superestrutural, segundo a concepção madura do revolucionário italiano da Sardenha, a educação não se desvincula da realidade material. Na verdade, a educação faz a mediação entre a realidade material e a superestrutura social, implicando no ensino e na aprendizagem de novas práticas sociais de acordo com a estrutura econômica, política e ideológica vigente. É por isso que Saviani, inspirado em Gramsci, entender por educação a "[...] produção no indivíduo singular da humanidade que é produzida histórica e coletivamente pelo conjunto dos homens.” (SAVIANI, 1992, p. 21).

Dessa forma entendida, a educação em Gramsci é eminentemente política, assim como a política passa a ser vista como comportando uma dimensão educativa. A educação é política porque interage no processo de produção e difusão de concepções de mundo e na transformação dessas em vontade coletiva. Por sua vez, a política, nas sociedades ocidentais, tem uma dimensão educativa porque, para reproduzir as relações sociais ou mesmo para superá-las é necessário desenvolver-se, também, como um processo educativo, e não apenas baseada na coerção. Eis porque Gramsci considera que "Toda relação de 'hegemonia' é necessariamente uma relação pedagógica” (GRAMSCI, 1999, p. 399).

Contudo, a educação não perde sua identidade na política, e nem a política deixa-se identificar cabalmente como educação. Nas sociedades ocidentais, elas são processos que têm suas próprias identidades, mas que, ao se efetivarem, interagem, intercomunicam-se, interferem mutuamente, perpassam-se dialeticamente.

Além disso, deve-se ressaltar que política e educação não são processos complemente autônomos em relação à dinâmica que se manifesta na base material. Pelo contrário, ambas articulam-se com a estrutura social, particularmente 
com o modo pelo qual os homens de determinada formação econômica e social historicamente produzem e reproduzem, pela prática produtiva, sócio-política e cultural simbólica que desenvolvem, na interação com os demais homens e com a natureza, as condições de existência, isto é, com o trabalho (cf. MARTINS, 2008c). "Ora, o ato de agir sobre a natureza transformando-a em função das necessidades humanas é o que conhecemos com o nome de trabalho. Podemos, pois, dizer que a essência do homem é o trabalho." (SAVIANI, 2007, p. 154). Eis porque, em Gramsci, "[...] o trabalho informa todo o processo educativo-escolar, desde a primeira infância." (NOSELLA, 1992, p. 82). Em outras palavras, o trabalho constitui-se, para Gramsci, como o princípio educativo fundamental. Mas trabalho compreendido na acepção marxista originária exposta, e não na compreensão que recorrentemente se tem dele como simples emprego, atividade laborativa desenvolvida nos moldes do modo de produção capitalista.

De fato, a tese gramsciana da união trabalho e educação não é uma originalidade, pois fora apresentada por Marx e Engels de passagem em algumas obras, por Lênin e mesmo por posteriores pensadores e protagonistas do socialismo. Contudo, principalmente nos cadernos 12 (Apontamentos e notas dispersas para um grupo de ensaios sobre a história dos intelectuais) e 22 (Americanismo e fordismo), Gramsci desenvolve uma visão da articulação entre trabalho e educação de maneira inovadora em relação às formulações anteriores, pois inserida na nova realidade das sociedades ocidentais e permeada pela intencionalidade da revolução socialista nesse novo contexto. Nos referidos Cadernos, o que se percebe é que, para Gramsci, o trabalho guarda centralidade na vida social e, como tal, articula-se dialeticamente com os demais processos sociais - em particular, com a educação -, sendo deles determinantes e sendo por eles retroalimentado. De fato, "A afirmação do trabalho como princípio educativo é um tema que pertence à essência do socialismo." (JESUS, 2005, p. 61).

Ocorre que a concepção burguesa de educação e de seu principal instrumento educativo, a escola, também se interessa em articular educação e trabalho, mas da forma que lhe convém, isto é, com a educação escolar e não escolar ${ }^{10}$ sendo formadoras da mão de obra necessária ao sistema produtivo burguês. Nesse sentido, a educação apregoada pela burguesia é imediatista e interessada, ou melhor, interesseira, pois quer apenas formar os homens de acordo com suas necessidades como classe dominante e dirigente. Foi isso que motivou a crítica de Gramsci, na segunda década do século XX, às propostas profissionalizantes para as escolas italianas. Nesse momento, a concepção gramsciana foi marcada

\footnotetext{
10 “[...] [n]o Caderno 12 [...] A noção de escola é [...] tomada no seu sentido mais amplo, isto é, refere-se a todo tipo de organização cultural para a formação de intelectuais; essas organizações são criadas e sustentadas historicamente pelas diferentes práticas ou forças produtivas da sociedade.” (NOSELLA, 1992, p. 108).
} 
pela oposição ao profissionalismo, pela defesa da educação desinteressada ${ }^{11}$, uma educação e uma escola comprometidas com a formação e difusão de uma cultura geral humanística e propedêutica. Mas cultura não no neutro sentido de "[...] saber enciclopédico, no qual o homem é visto apenas sob a forma de um recipiente a encher e entupir de dados empíricos” (GRAMSCI, 2004, p. 57), pois esta não é interessante ao proletariado pelo restrito impacto ético-político que dela decorre, e sim entendida como "[...] organização, disciplina do próprio eu interior, apropriação da própria personalidade, conquista da consciência superior [...] (GRAMSCI, 2004, p. 58), com vista a elevar a consciência de si e do mundo, rearticulando a própria personalidade e inovando as práticas sociais, concebendo-se como protagonista do próprio destino, condição necessária à superação do capitalismo e à construção de uma nova civilização, o socialismo.

Porém, essa posição em favor de uma educação e de uma escola desinteressada amadurece em Gramsci no período do pós-guerra. Nele, a concepção educativa gramsciana é marcada pela problemática dos conselhos de fábrica e dos desafios em se construir um estado proletário. Assim, a ênfase ao aspecto cultural como reivindicação de conteúdo para a formação proletária passa a ser articulado com a necessidade de o partido e o sindicato sustentarem iniciativas educacionais concretas, tendo como princípio o moderno trabalho industrial e como referência o embrião do futuro estado proletário presente em germe nos conselhos de fábrica. Começa, portanto, a ganhar mais clareza no desenvolvimento do pensamento gramsciano a ideia da necessária unidade entre cultura e trabalho, humanismo e tecnologia como características de um almejado processo de formação para o proletariado. Foi essa compreensão que orientou o grupo em torno da revista Ordine Nuovo a criar, no final de 1920, uma escola de cultura e de propaganda socialista, pautada na experiência e nos desafios dos conselhos de fábrica. Entretanto, posteriormente, com a ascensão do fascismo, Gramsci viu-se com a necessidade de reorientar as propostas educacionais, tornando-as mais imediatistas e mesmo interessadas em formar quadros para o partido em todas as partes, para elevar a consciência das massas, obscurecida pela propaganda e cooptação. Tendo em vista a repressão do fascismo, a única forma possível pensada por Gramsci foi a de construir uma escola por correspondência, com a finalidade de promover uma primeira formação, não tão aprofundada, no período de repressão, visando ao posterior aprofundamento e aprimoramento com a pretendida abertura política resultante da queda do fascismo.

Mesmo preso, com o endurecimento do fascismo, Gramsci fundou uma escola no cárcere junto com amigos e militantes para atender às necessidades dos

\footnotetext{
${ }^{11}$ Para Nosella (1992, p. 14), por “[...] 'desinteressado' [entende-se] (cultura desinteressada, escola e formação desinteressadas) que conota horizonte amplo, de longo alcance, isto é, que interessa objetivamente não apenas a indivíduos ou a pequenos grupos, mas à coletividade e até à humanidade inteira."
} 
encarcerados: desde os analfabetos, até os letrados, mas que precisavam do debate científico-filosófico para não embrutecerem seus corações e mentes frente à limitada situação de encarcerado.

As reflexões teóricas, o embate político na militância e a práxis política de Gramsci criaram um rico caldo que fez amadurecer a sua proposta educativa, fazendo-a desenvolver-se até atingir a concepção de educação e de escola desenvolvidas no cárcere: a escola unitária. Ela considera a centralidade do trabalho nas relações sociais, e o que Gramsci propõe é que a escola seja um meio pelo qual os homens de uma determinada formação econômica e social possam conhecer amplamente o mundo do trabalho, seus processos, métodos, técnicas e finalidades, nas suas várias modalidades, para que tenham as condições de, apropriando-se desses conhecimentos e dessas habilidades historicamente produzidos, superar o modo de produção capitalista da vida social em busca da construção de uma nova civilização. Inspirada no processo produtivo mais "evoluído" à sua época, a indústria moderna, sobretudo na racionalização e disciplina que a caracterizava, considerando, inclusive, as críticas a ela pela alienação que promove com a separação entre trabalho intelectual e trabalho manual, por exemplo, a escola unitária de Gramsci recomenda a união em um mesmo processo escolar do saber, isto é, do tradicional ensino humanista (NOSELLA, 1992, p. 20) e propedêutico, com o fazer, que é orientado, nas modernas sociedades, pela racionalização científica e tecnológica.

A finalidade do processo educativo propugnado por Gramsci é a formação de homens integrais, algo bem próximo da formação omnilateral proposta pelo marxismo originário" 12 . De fato, "[...] Gramsci, ao delinear o tipo de homem harmoniosamente desenvolvido, que já fora indicado por Marx e Engels, [...] voltou a propor, embora consciente de sua aproximação [...]" (MANACORDA, 1990, p. 107). Obviamente, pela sua base de referência no materialismo histórico e dialético, a integralidade da formação humana proposta por Gramsci articula-se com a necessidade, sobretudo, das classes subalternas, de produzir novos intelectuais, intelectuais próximos do povo, aptos a sentir o que o povo sente para poder produzir concepções de mundo que se transformem em vontade coletiva, entendida por Gramsci como força material da história. Daí a necessidade do vínculo orgânico, vital, entre intelectuais e povo, os indivíduos e grupos sociais integrantes das classes subalternas (GRAMSCI, 1999, p. 221-222).

A escola unitária proposta por Gramsci tem como objetivo, também, formar esse intelectual orgânico às classes subalternas. Assim, ela deve ser universal,

\footnotetext{
${ }^{12}$ Há um debate significativo sobre a melhor forma de identificar proposta educativa de Marx e Engels. Cf., por exemplo, os argumentos de Frigotto (1991) e de Saviani (1989 e 2007), que identificam a proposta educativa marxista originária, influenciados por Lênin, com o termo "politecnia", e de Nosella (2007), que, inspirado em Manacorda (1991), prefere o termo "omnilateral".
} 
pública, gratuita, obrigatória e de período integral, com vistas a superar, sob o ponto de vista do conteúdo e do método, a escola tradicional e religiosa, as escolas profissionalizantes burguesas e mesmo as escolas de partido, que visavam a formar quadros para o processo revolucionário e mesmo para depois de sua efetivação com a instituição do socialismo, algo que o próprio Gramsci defendeu nos primórdios da década de vinte do século passado. A escola unitária "[...] deveria seguir esta linha: escola única inicial de cultura geral, humanista, formativa, que equilibre de modo justo o desenvolvimento da capacidade de trabalhar manualmente (tecnicamente, industrialmente) e o desenvolvimento das capacidades de trabalho intelectual.” (GRAMSCI, 2000a, p. 33). De fato, Gramsci, não joga fora a água com a criança dentro, pois resgata a importância da desinteressada formação humanística, que é herança do ensino tradicional, sem deixar de questioná-lo e negá-lo principalmente por seu autoritarismo, e, também, recupera a interessada profissionalização do ensino, sobretudo, das escolas burguesas, não deixando de criticar seu imediatismo. Faz isso integrando-as de uma nova forma, a forma da escola unitária. Eis "[...] dois temas centrais da reflexão pedagógica gramsciana: a opção metodológica entre espontaneismo e autoritarismo, e a opção conteudística entre instrução intelectual tradicional e a instrução moderna tecnológica." (MANACORDA, 1990, p. 66).

Sob o ponto de vista do conteúdo, a proposta gramsciana de escola unitária pretendia socializar universalmente os conhecimentos historicamente produzidos, até mesmo porque, se eles são interpretados como resultantes da produção coletiva da humanidade, devem ser apropriados não privadamente, mas coletivamente pelo conjunto dos homens para que possam dispor, igualmente, das mesmas condições no processo de luta pela existência e, também, para conseguirem elevar suas consciências, transformando qualitativamente suas práticas produtivas, sócio-políticas e culturais-simbólicas individuais e coletivas. Assim, o patrimônio cultural, filosófico, científico e tecnológico deveria compor o conteúdo da escola unitária, o qual seria desenvolvido por um método que partisse "[...] das experiências concretas de todos, valorizando-as e estudando-as coletivamente, de forma que o grupo todo se torne educador de si mesmo, organicamente, elevando o nível cultural de cada um e do conjunto" (NOSELLA, 1992, p. 72), por meio um processo racional, em que a disciplina (disciplina externa ao educando articulada à sua autodisciplina) nos estudos, nas reflexões e nas ações fosse motivada, juntamente com o estímulo à autonomia e liberdade de criação, as quais deveriam ser exercitadas. A ênfase metodológica varia, em Gramsci, conforme o desenvolvimento psicológico do educando: enquanto na fase infantil, a disciplina, a autodisciplina e a intervenção externa do educador deveria sem temperada com o afeto, dando liberdade à criatividade para combater o dogmatismo e estimular a expansão autônoma e responsável 
da personalidade, e não o ativismo pregado pelo escolanovismo, que resulta em conformismo, na juventude, "[...] fase decisiva, na qual se tende a criar os valores fundamentais do "humanismo" (GRAMSCI, 2000a, p. 39), maior estímulo deveria ter "[...] a autodisciplina intelectual e autonomia moral necessárias a uma posterior especialização, seja ela de caráter científico (estudos universitários), seja de caráter imediatamente prático-produtivo (indústria, burocracia, comércio)" (GRAMSCI, 2000a, p. 39). Ou seja, ao jovem da escola unitária deveria incidir menor intervenção externa, mas dele ser cobrada maior racionalidade - que educa a fantasia abstrata, tornando-a concreta -, disciplina, autonomia moral e elevação da consciência.

Portanto, “[...] é com base na evolução psicológica do homem que estabelece princípios educativos metodológicos diferenciados para o ensino de $1^{\circ}, 2^{\circ} \mathrm{e}$ $3^{\circ}$ graus" (GRAMSCI, 2000a, p. 81), considerando que os processos educativos diferenciados devem seguir "[...] os dados subjetivos do desenvolvimento psicológico dos jovens" e, também, "[...] os dados objetivos dos fins a serem alcançados, que é o de introduzir na vida social os jovens, dotados de certa autonomia intelectual e de uma capacidade de criação intelectual e prática ao mesmo tempo, e de orientação independente." (MANACORDA, 1990, p. 158).

Em relação aos tempos escolares, Gramsci (2000a, p. 37) observa que

A escola unitária deveria corresponder ao período representado hoje pelas escolas primárias e médias [...] O nível inicial da escola elementar não deveria ultrapassar três-quatro anos e, ao lado do ensino das primeiras noções 'instrumentais' da instrução (ler, escrever, fazer contas, geografia, história), deveria desenvolver sobretudo a parte relativa aos 'direitos e deveres', atualmente negligenciada, isto é, as primeiras noções do Estado e da sociedade, enquanto elementos primordiais de uma nova concepção do mundo que entra em luta contras as concepções determinadas pelos diversos ambientes sociais tradicionais, ou seja, contra as que poderíamos chamar de folclóricas [...] O resto do curso não deveria durar mais de seis anos, de modo que, aos quinze ou dezesseis, já deveriam estar concluídos todos os graus da escola unitária.

Daí resulta que o processo de formação da escola unitária ganharia contornos de uma escola viva, articulada ao patrimônio histórico-cultural e, ao mesmo tempo, organicamente comprometida com a superação dos problemas vivenciados pela sociedade resultante do desenvolvimento das forças produtivas da moderna sociedade industrial. Nessa escola, "instrução", que se refere à preocupação com os conteúdos, e "educação", que se relaciona ao "[...] problema da ordem intelectual e moral" (MANACORDA, 1990, p. 178) deveriam estar unidos, pois "A escola unitária [...] deveria assumir a tarefa de inserir os jovens na atividade social, depois de tê-los elevado a certo grau de maturidade e capacidade para a criação intelectual e prática e a certa autonomia na orientação 
e na iniciativa." (GRAMSCI, 2000a, p. 36) A escola proposta partiria do senso comum, criticando-o com os instrumentais racionais, com o intuito de superá-lo como concepção de mundo e como orientador da prática social, do que resultaria a elevação da consciência que os indivíduos e os grupos sociais têm de si e do mundo, bem como a transformação das práticas sociais individuais e coletivas.

Assim, o perfil de aluno a ser formado seria o de um intelectual não tradicional, pois "O velho tipo de intelectual [que] era o elemento organizador de uma sociedade de base predominantemente camponesa e artesã; [...] [mas] um novo tipo de intelectual: organizador técnico, o especialista da ciência aplicada" (GRAMSCI, 2004, p. 424). Ou seja,

O modo de ser do novo intelectual não pode mais consistir na eloquência, motor exterior e momentâneo dos afetos e das paixões, mas numa inserção ativa na vida prática, como construtor, organizador, "persuasor permanente", já que não apenas orador puro - mas superior ao espírito matemático abstrato; da técnica-trabalho, chega à técnica-ciência e à concepção humanista histórica, sem a qual permanece 'especialista' e não se torna “dirigente” (especialista + político). (GRAMSCI, 2004, p. 53).

A escola unitária seria, portanto, o instrumento que possibilitaria a formação prévia integral e única que todos os indivíduos de determinada formação econômica e social deveriam ter para adquirirem as condições de ser governantes e governados. Por isso, “[...] deve-se não multiplicar e hierarquizar os tipos de escola profissional, mas criar um tipo único de escola preparatória (primário-média) que conduza os jovens até os umbrais da escolha profissional, formando-o, durante este meio tempo, como pessoa capaz de pensar, de estudar, de dirigir ou de controlar quem dirige.” (GRAMSCI, 2000a, p. 49). No Ensino Superior, chegariam homens e mulheres não profissionalizados precocemente, como pretendiam as escolas profissionais burguesas, mas sujeitos com elevada consciência de si e do mundo, bem como aptos a desenvolverem qualquer aptidão técnico-profissional que, autonomamente, julgar procedente para si. Nesse sentido, "O advento da escola unitária significa o início de novas relações entre trabalho intelectual e trabalho industrial não apenas na escola, mas em toda vida social." (GRAMSCI, 2000a, p. 40). Eis algo bastante diferente da reforma de Gentile, criticada por Gramsci porque restringiu aos trabalhadores à escola elementar e ao ensino profissionalizante.

Em relação ao Ensino Superior, a proposta educativa de Gramsci não poderia ser forjada senão de forma semelhante à proposta de escola elementar e média. Ela também nasceu da própria experiência de Gramsci nesse nível de ensino (MANACORDA, 1990), de sua crítica à universidade tradicional, à tradição burguesa universitária e às reformas educacionais, emergindo da 
intencionalidade revolucionária de Gramsci de produzir uma nova civilização, o que, segundo ele, exige também uma nova cultura. Toma como referência para a reflexão sobre o nível superior "[...] a ausência de influência da universidade na vida cultural [italiana]" (MANACORDA, 1990, p. 119). Propõe, então, uma universidade capaz de romper o distanciamento entre professor e aluno, que tenha uma didática que não se reduza à retórica e nem trabalhe com a perspectiva epistemológica da verdade instituída, herança religiosa; propõe, ainda, a difusão de valores humanísticos e o exercício da pesquisa dos problemas vigentes, de forma a colaborar com a construção de uma nova cultura, que é necessária à construção de uma nova sociedade. Essa nova instituição é, de fato, uma “[...] 'escola' de alta cultura, de elaboração crítica e científica, imprescindível a qualquer hegemonia.” (JESUS, 2005, p. 75).

Toda a concepção educativa de Gramsci o aproximou e o afastou de Rousseau. Aproximou porque Gramsci entendeu que a criança e o jovem devem ser formados - eles não são adultos em miniatura! - sem o imediatismo das escolas burguesas e sem considerar que trazem em si, inatamente, dons naturais ${ }^{13}$, como concebia a visão tradicional, sobretudo, religiosa, de educação. De fato, "Não se levou em conta que as ideias de Rousseau são uma violenta reação contra a escola e os métodos pedagógicos dos jesuítas e, enquanto tal, representam um progresso [...]" (GRAMSCI, 2000a, p. 62). Além disso, Gramsci, com essa concepção, está próximo de Rousseau porque entende que o processo educativo deveria se desenvolver de forma articulada ao desenvolvimento infantil e juvenil, com vista a formar amplamente os educandos, para prepará-los para enfrentar os desafios que a vida lhes impuser. Ou seja, assim como em Rousseau, para Gramsci, a decorrência do processo formativo da criança, do indivíduo, o Emílio, é que ele esteja preparado para viver em sociedade, isto é, se transforme em cidadão e, assim, produza uma sociedade diferente,

[...] democrática [que], intrinsecamente, não pode significar apenas em que um operário manual se torne qualificado, mas em que cada "cidadão" possa se tornar "governante" e que a sociedade o ponha, ainda que "abstratamente", nas condições gerais de poder fazê-lo: a democracia política tende a fazer coincidir governantes e governados (no sentido de governo com o consentimento dos governados), assegurando a cada governado a aprendizado gratuito das capacidades e da preparação técnica geral necessárias a essa finalidade. (GRAMSCI, 2000a, p. 50).

Por outro lado, Gramsci afasta-se de Rousseau por não compreender o homem apenas como um ser naturalmente bom, ou mau, mas como resultante

\footnotetext{
13 "Não é tampouco por acaso que Gramsci retoma aqui uma de suas antigas expressões: o homem como formação (ou "criação"), que já encontramos no artigo de 1916, intitulado Socialismo e cultura, dentro de um severo contexto antiespontaneísta, mas perpassado de idealismo: 'o homem é sobretudo espírito, isto é, criação histórica e não natureza"' (MANACORDA, 1990, p. 74).
} 
de um conjunto de fatores (econômicos, sociais, políticos, culturais, filosóficos, psicológicos, éticos, estéticos etc.) e forças histórico-sociais que dialeticamente nele incidem e o produz tal qual é.

De forma coerente, Gramsci identifica, sob o signo da equação inatismo = renúncia a educar, os conceitos de "natural", "casual", "caótico", "mecânico"; natureza, isto é, ambiente, quer dizer causalidade e caos. Por isso a educação para ele é uma adaptação ao ambiente, sim, mas também e, sobretudo, uma luta contra esse ambiente, para não permitir que esse influa casualmente, mecanicamente, talvez mesmo através de seus aspectos menos evoluídos, e por isso como "autoridade", como "pressão". O problema coloca-se como uma opção entre naturalidade e autoridade, isto é, intervenção humana, na pressuposição de que não se pode falar da natureza do homem, mas tão-somente de um ambiente historicamente determinado. (MANACORDA, 1990, p. 81).

A educação propugnada por Gramsci exige a intervenção do educador, que deve fazer a mediação entre o jovem e a sociedade, estimulando o desenvolvimento da autonomia intelectual e moral do educando. Para a escola unitária de Gramsci, o desenvolvimento do ser infantil e juvenil não deve acontecer de forma "espontânea", delimitada apenas e tão somente pelo interesse e pela atividade da criança. De fato, a partir das formulações Rousseau,

[...] formou-se uma espécie de igreja, que paralisou os estudos pedagógicos e deu lugar a curiosas involuções [...] A "espontaneidade" é um dessas involuções [...] Na realidade a geração educa a nova geração, isto é, forma-a; a educação é uma luta contra os instintos ligados às funções biológicas elementares, uma luta contra a natureza, a fim de dominá-la e criar o homem "atual" à sua época. Não se leva em conta que o menino, desde quanto começa a "ver e a tocar" [...] acumula sensações e imagens, que se multiplicam e se tornam complexas com o aprendizado da linguagem. A "espontaneidade", se analisada, torna-se cada vez mais problemática. De resto, a "escola" [...] é somente uma fração da vida do aluno, o qual entra em contato tanto com a sociedade humana quanto com a societas rerum, formando-se critérios a partir dessas fontes "extraescolares" muito mais importantes do que habitualmente se crê. A escola única, intelectual e manual, tem ainda esta vantagem: a de colocar o menino em contato, ao mesmo, tempo, com a história humana e com a história das "coisas", sob o controle do professor. (GRAMSCI, 2000a, p. 62-63).

Deixar a criança desenvolver-se pela sua própria natureza, espontaneamente, possibilitará que tenha a personalidade orientada pela caótica noção de mundo que traz consigo e que está na realidade como senso comum e folclore, que expressam, a seu modo, a intencionalidade presente na dinâmica das forças e estruturas sociais vigentes. Ou seja, 
Toda a atitude de respeito à espontaneidade, em sua aparência de respeito pela natureza da criança, é, na realidade, renúncia a educar, a formar o homem segundo um plano humano; é o abandono completo da criança ao autoritarismo, ou seja, à pressão exercida objetivamente pelo ambiente. Esta é a conclusão amadurecida a que chega Gramsci. (MANACORDA, 1990, p. 75).

A intencionalidade da proposta da escola unitária reside no fato de que as crianças e jovens tenham sua formação dirigida para os fins que são indispensáveis para a construção de uma nova civilização, a sociedade socialista, daí a compreensão gramsciana de que o professor "[...] antes de tudo, representa a consciência crítica da sociedade.” (JESUS, 2005, p. 79). Ou seja, Gramsci “[...] desloca a ênfase, dos professores como indivíduos singulares, para todo o complexo social." (MANACORDA, 1990, p. 245).

Todavia, para ser implantada, essa proposta de escola unitária exige que a sociedade também se desenvolva por outros meios, com princípios e finalidades distintos da sociedade capitalista. Assim se constitui, no legado gramsciano, a dialética tensão entre promover mudanças na escola para transformar a sociedade ou promover as transformações sociais para mudar a escola. Nas palavras de Betti, tem-se que

Desde suas primeiras intervenções no Ordine Nuovo, Gramsci insiste no caráter político do problema educacional, e manifesta uma convicção de que o problema da escola, da difusão da instrução, é um aspecto decisivo para uma reforma democrática de toda a vida social do país; assim mesmo, está convencido de que a luta por uma escola única para todo o povo abre uma perspectiva socialista e representa um componente essencial da luta política sustentada pela classe operária para a afirmação de sua hegemonia. (BETTI, 1981, p. 170).

Gramsci tem, portanto, uma visão ampla de educação: compõe-se de todos os processos sociais que mediatizam a vida social e se caracterizam por processos de ensino e aprendizagem que se desenvolvem na escola e fora dela. É por essa concepção que Gramsci critica a educação burguesa, a educação fascista e religiosa, bem como encontra sustentação para forjar a concepção de escola unitária, que articula os processos de ensino-aprendizagem com a dinâmica real da vida social, para promover as condições necessárias à construção de uma nova civilização. Uma escola que deve prover "[...] a formação para a capacidade de agir ao mesmo tempo intelectualmente e manualmente (isto é, no mundo contemporâneo, tecnicamente, industrialmente), em uma organização educativa unitária, vinculada às instituições produtivas e culturais da sociedade adulta." (MANACORDA, 1990, p. 285). 


\section{Considerações finais}

À guisa de conclusão, resta retomar algumas ideias que perpassaram este texto e que merecem ser reforçadas quando se trata de discutir o legado de Gramsci, em particular, suas formulações sobre filosofia e educação.

$\mathrm{O}$ fato de que Gramsci nunca tenha escrito um livro, mas haver vários livros publicados com textos do comunista revolucionário nascido na Sardenha torna imperativo afirmar que a abra teórico-metodológica de Gramsci não pode ser lida e interpretada isoladamente, porque forma uma totalidade que, para ser bem compreendida, exige ser tomada integral e historicamente. Apenas assim se terá condições de acompanhar o desenvolvimento e o amadurecimento dos conceitos e da própria práxis desenvolvida por Gramsci ao longo de sua vida, até chegar ao período da maturidade intelectual representada pela produção realizada no cárcere. Dessa tese decorre uma orientação à leitura dos textos de Gramsci, que são assistemáticos pelas condições em que foram produzidos, mas que não podem ser apropriados indebitamente, como fazem alguns liberais e idealistas, pois essas concepções e práxis contradizem o legado de Gramsci.

As diferentes edições dos Cadernos do cárcere de Gramsci, sua obra de maturidade, colaboraram muito, cada qual à sua maneira, para que atualmente se tenha melhores condições de entender e interpretar o legado teórico do marxista revolucionário da Sardenha. Contudo, a leitura da obra de Gramsci ainda permanece mais complicada do que a de autores que escreveram, revisaram e publicaram seus livros. Assim, a exigência da boa hermenêutica de não ler a obra fora do contexto, no caso do legado de Gramsci, exige alguns procedimentos, principalmente os quatro seguintes: conhecer o contexto histórico em que ele viveu; identificar os embates éticos, políticos, ideológicos e culturais que travou, sobretudo, no interior do movimento comunista italiano e internacional; reconhecer os autores com os quais dialogou; familiarizar-se com as polêmicas teóricas que enfrentou no momento em que redigia seus textos. Dessa forma se terá melhores condições para bem entender a obra de Gramsci, ou seja, para interpretá-lo é imperativo se ter como referência a realidade histórica por ele vivida - seus limites, possibilidades e contradições - e a posição que adotou frente aos desafios que enfrentou. Em outras palavras, pode-se dizer que, embora os escritos gramscianos sejam fragmentários, eles guardam coerência política, ideológica e teórica interna, coesão que se estende para a práxis por ele desenvolvida, do que decorre poder interpretar a vida concreta de Gramsci e sua produção teórica como uma totalidade articulada.

Em geral, os conceitos formulados por Gramsci são profundamente contaminados pela noção dialética e politizada que ele tem da relação entre estrutura e superestrutura. Em particular, a filosofia e a educação ganham, no legado 
gramsciano, tonalidades políticas com princípios e finalidades bem definidos, quais sejam aqueles do paradigma teórico-metodológico materialista histórico e dialético, e tornam-se, assim, processos e produtos das relações sociais.

\section{Referências}

BETTI, G. Escuela, educación y pedagogía en Gramsci. Tradução de J. A. B. Barcelona: Ediciones Martínez Roca, 1981. (Colección Novo Curso).

BOBBIO, N. O conceito de sociedade civil. Tradução de Carlos Nelson Coutinho. 2. ed. Rio de Janeiro: Edições Graal, 1982.

CARDOSO, M. L. Ideologia e desenvolvimento. Brasil: JK-JQ. 2. ed. Rio de Janeiro: Paz e Terra, 1978. (Coleção Estudos Brasileiros, v. 14).

COUTINHO, C. N. Introdução. In: GRAMSCI, A. Cadernos do cárcere: Introdução ao estudo da filosofia: a filosofia da Benedetto Croce. Edição e tradução de Carlos Nelson Coutinho, coedição de Luiz Sérgio Henriques e Marco Aurélio Nogueira. Rio de Janeiro: Civilização Brasileira, 1999. v. 1.

Gramsci: um estudo sobre seu pensamento político. Nova edição rev. e ampl. Rio de Janeiro: Civilização Brasileira, 1999.

DORE, R. Gramsci e o debate sobre a escola pública no Brasil. Cadernos Cedes, Campinas, v. 26, n. 70, p. 329-352, set./dez. 2006. DOI: 10.1590/S0101-32622006000300004

FINELLI, R. As contradições da subjetividade: americanismo e fordismo em Antonio Gramsci, 2001. Disponível em: <http://www.artnet.com.br>. Acesso em: 18 dez. 2008.

FRIGOTTO, G. Tecnologia, relações sociais e educação. Tempo Brasileiro, Rio de Janeiro, n. 105, p. 131-148, abr./jun. 1991.

GRAMSCI, A. Cadernos do cárcere: introdução ao estudo da filosofia; a filosofia da Benedetto Croce. Edição e tradução de Carlos Nelson Coutinho, coedição de Luiz Sérgio Henriques e Marco Aurélio Nogueira. Rio de Janeiro: Civilização Brasileira, 1999. v. 1.

Cadernos do cárcere: os intelectuais; o princípio educativo; jornalismo. Edição e tradução de Carlos Nelson Coutinho, coedição de Luiz Sérgio Henriques e Marco Aurélio Nogueira. Rio de Janeiro: Civilização Brasileira, 2000a. v. 2.

Cadernos do cárcere: Maquiavel; notas sobre o estado e a política. Edição e tradução de Carlos Nelson Coutinho, coedição de Luiz Sérgio Henriques e Marco Aurélio Nogueira. Rio de Janeiro: Civilização Brasileira, 2000b. v. 3.

Cadernos do cárcere: temas de cultura. Ação católica. Americanismo e fordismo. Edição e tradução de Carlos Nelson Coutinho, co-edição de Luiz Sérgio Henriques e Marco Aurélio Nogueira. Rio de Janeiro: Civilização Brasileira, 2001. v. 4.

Escritos políticos: 1910-1920. Organização e tradução de Carlos Nelson Coutinho. Rio de Janeiro: Civilização Brasileira, 2004. v. 1.

Cartas do cárcere: 1931-1937. Tradução de Luiz Sérgio Henriques. Organização de Carlos Nelson Coutinho e Luiz Sérgio Henriques. Rio de Janeiro: Civilização Brasileira, 2005. v. 2. 
GRISONI, D.; MAGGIORI, R. Ler Gramsci. Lisboa: Iniciativas Editoriais, 1973.

GRUPPI, L. O conceito de hegemonia em Gramsci. Tradução de Carlos Nelson Coutinho. 2. ed. Rio de Janeiro: Edições Graal, 1978. (Biblioteca Estudos Humanos; Série Teoria Política, n. 1).

JESUS, A. T. de. O pensamento e a prática escolar de Gramsci. 2. ed. Campinas: Autores Associados, 2005. (Coleção Educação contemporânea).

LÊNIN, V. I. Cadernos filosóficos. Buenos Aires: Ediciones Estudio, 1972.

O Estado e a revolução. São Paulo: Hucitec, 1986.

LOSURDO, D. Os primórdios de Gramsci: entre o Risorgimento e a I Guerra Mundial. Caderno Cedes, Campinas, v. 26, n. 70, p. 291-310, set./dez. 2006. DOI: 10.1590/S010132622006000300002

MANACORDA, M. A. O princípio educativo em Gramsci. Tradução de William Lagos. Porto Alegre: Artes Médicas, 1990.

Marx e a pedagogia moderna. Tradução de Newton Ramos de Oliveira. São Paulo: Cortez; Campinas: Autores Associados, 1991.

MARTINS, M. F. Sociedade civil e "terceiro setor": apropriações indébitas do legado teóricometodológico de Gramsci. Revista de Filosofia Aurora, Curitiba, v. 20, n. 26, p. 75-100, jan./jun. 2008a.

Marx, Gramsci e o conhecimento: ruptura ou continuidade? Campinas: Autores Associados; Americana: Unisal, 2008b. (Coleção Educação Contemporânea).

Pedagogia do engajamento: considerações sobre a desumanização e as possibilidades de sua superação. Práxis Educativa, Ponta Grossa, v. 3, n. 1, p. 55-66, jan./jun. 2008c. DOI: 10.5212/PraxEduc.v.3i1055066

Gramsci, os intelectuais e suas funções científico-filosófica, educativo-cultural e política. Pro-Posições, Campinas, v. 22, n. 3, p. 131-148, set./dez. 2011a. DOI: 10.1590/ S0103-73072011000300010

Práxis e "catarsis" como referências avaliativas das ações educacionais das ONG's, dos sindicatos e dos partidos políticos. Avaliação, Campinas, v. 16, n. 3, p. 533-558, nov. 2011b. DOI: 10.1590/S1414-40772011000300003

MARX, K. As lutas de classes em França. Tradução de Álvaro Pina e Fernando Silvestre. Moscou; Lisboa: Edições Avante-Edições Progresso, 1984. (Biblioteca do marxismoleninismo, n. 18).

Manuscritos econômicos e filosóficos e outros textos escolhidos. Tradução José Carlos Bruni. 5. ed. São Paulo: Nova Cultural, 1991. (Coleção Os Pensadores, v. 12).

Para a crítica da filosofia do direito de Hegel. Tradução de Artur Mourão. Covilhã: Universidade da Beira Interior, 2008. (Coleção Textos Clássicos LusoSofia).

MARX, K.; ENGEL, F. O manifesto comunista. Tradução de Maria Lúcia Como. Rio de Janeiro: Paz e Terra, 1997. (Coleção Leitura).

NOSELLA, P. A escola de Gramsci. Porto Alegre: Artes Médicas Sul, 1992. 
Trabalho e perspectivas de formação dos trabalhadores. Revista Brasileira de Educação, Rio de Janeiro, v. 12, n. 34, p. 137-151, jan./abr. 2007. DOI: 10.1590/S141324782007000100011

RAGAZZINI, D. Teoria da personalidade na sociedade de massa: a contribuição de Gramsci. Tradução de Maria de Lourdes Menon. Campinas: Autores Associados, 2005.

SAVIANI, D. Sobre a concepção de politecnia. Rio de Janeiro: EPSJV/Fiocruz, 1989.

Pedagogia histórico-crítica: primeiras aproximações. 3. ed. São Paulo: Cortez; Autores Associados, 1992. (Coleção Polêmicas do nosso tempo, v. 40).

Trabalho e educação: fundamentos ontológicos e históricos. Revista Brasileira de Educação, Rio de Janeiro, v. 12, n. 34, p. 152-165, jan./abr. 2007. DOI: 10.1590/S141324782007000100012

SEMERARO, G. Anotações para uma teoria do conhecimento em Gramsci. Revista Brasileira de Educação, Rio de Janeiro, n. 16, p. 95-104, jan./abr. 2001. DOI: 10.1590/ S1413-24782001000100010

STACCONE, G. Gramsci - 100 anos: revolução e política. 3. ed. Petrópolis: Vozes, 1995.

Recebido em 12/04/2012

Versão final recebida em 12/08/2012

Aceito em 16/08/2012 